\title{
Sources of Information about STI/HIVIAIDS Used by Adolescent Students
}

\begin{abstract}
Débora Amorim de Vasconcelos ${ }^{1}$, Maria Mônica Paulino do Nascimento ${ }^{2}$ Cláudia Jeane Lopes Pimenta1, Thaynara Ferreira Filgueiras ${ }^{3}$, Marleny Andrade Abreu ${ }^{4}$, Mariel Wágner Holanda Lima ${ }^{5}$, Milena Nunes Alves de Sousa ${ }^{6}$, Matheus Fontes Leite ${ }^{7}$, Hermínia Monalisa Pereira de Sousa Barreto ${ }^{8}$, Kariny Kelly de Oliveira Maia9 ${ }^{9}$ Claryssa Queiroz de Oliveira1, Adriana Ramalho Nascimento', Fernanda Thamy Feitosa Valêncio', Rayssa Dantas de Araújo1, Ronney Alves Braga dos Santos ${ }^{10}$
\end{abstract}

\section{Abstract}

Introduction: Adolescence is a stage is which several transformations occur in the individual's body, besides being the period of greatest vulnerability to Sexually Transmitted Infections (STI), especially HIVI AIDS, as sexuality and the search for pleasure are salient features of the adolescent individuals.

Objective: Identify the sources of information about STI/HIVIAIDS used by adolescent students.

Method: This is an exploratory, descriptive and transversal field study, with a quantitative approach, carried out in a public high school, located in the urban area of the municipality of Cajazeiras/PB, with 188 adolescents of a population base of 288 students, between the months of February and March 2015. The data was collected during the school term period, by means of a previously elaborated questionnaire, and analyzed with the SPSS (Statistical Package for the Social Science) for Windows, version 21.

Results: 188 adolescents took part in this study, of whom the majority was composed of the female individuals, aged between 17 and 19 years, self-declared black or brown-skinned, without a partner , catholic, with a family income of up to a minimum salary and who
1 Bachelor of Nursing, Federal University of Campina Grande. Cajazeiras, Paraiba, Brazil.

2 Master Student of Collective Health, Catholic University of Santos. Santos, São Paulo, Brazil.

3 Obstetrics Nursing Resident, School of Public Health of Ceará. Fortaleza, Ceará, Brazil.

4 Post-graduate Student in Urgency and Emergency and Intensive Care Unit Nursing, Faculty of Santa Maria. Cajazeiras, Paraíba, Brazil.

5 Odontology Student, Stadual University of Rio Grande of Norte. Caicó, Rio Grande do Norte, Brazil.

6 Nurse. Doctor in Health Promotion by Franca University. Teacher at the Integrated Faculties of Patos. Cajazeiras, Paraíba, Brazil.

7 Medicine Student, Federal University of Campina Grande. Cajazeiras, Paraiba, Brazil.

8 Post-graduate Student in Urgency and Emergency Nursing, Faculty of Santa Maria. Cajazeiras, Paraíba, Brazil.

9 Specialist in Family and Community Health, Open University of the National Health System. Brazil.

10 Bachelor of Medicine, Faculty of Medicine Nova Esperança. João Pessoa, Paraíba, Brazil.

\section{Contact information:}

Cláudia Jeane Lopes Pimenta.

$\risingdotseq$ claudinhajeane8@hotmail.com 
stated not to work. About the sources of information, it became clear that the school and the media were the most cited by the adolescents of both genders.

Conclusion: It was observed that the social and economic spheres may increase the adolescents' vulnerability to STI/HIVIAIDS and that the school made a relevant contribution to the dissemination of knowledge on the topic.

\section{Keywords}

Adolescent; Sexually

Transmitted Infections;

Sources of information.

\section{Introduction}

Adolescence is considered to be a transitional phase between childhood and adult life, which is marked by biological, physical, psychological and social modifications [1]. The modifications which occur during this period, associated to the conflicts and complexities related to each adolescent, cause them to intensely experience sexuality, manifesting itself, many times, by means of unprotected sexual practices [2].

This conjuncture has been characterized as a public health matter, as the adolescent and young adult population is considered to be a risk group for the contamination by Sexually Transmitted Infections (STI), especially the HIV/AIDS, being considered as a priority target public for the prevention campaigns against STIs, both nationally and worldwide [3-4].

The number of HIV cases in 15 to 19 year-old individuals has been presenting a rapid rise over the years, seen as in 2007 corresponded to 250 cases, totaling $4.3 \%$ of the infected population, while in 2014, 1.364 cases of infected adolescents were notified, representing $5.7 \%$ of the total HIV cases in the country. Furthermore, the detection rate for cases of AIDS in this age group in Brazil almost doubled in a decade, in 2002, corresponding to 3.4 cases for each 100.00 inhabitants, and suffering a sharp increase to 5.3 cases per 100.000 inhabitants in 2015 [5].
There are several situations which provide vulnerabilities to STI/HIVIAIDS in adolescence, and have been verified by the increase in the prevalence of various infections in this phase of life. Sexuality for the adolescents has been manifested via unprotected sexual intercourse, which relates, in the majority of cases, to the lack of information and communication among the family members about the theme, resulting in the adolescent's search in non-trustworthy sources for the acquisition of knowledge $[2,6]$.

Added to this is the fear of assuming a sexually active life and the existence of myths and taboos established by society, which directly influences the discovery of sexuality by the adolescent, encouraging them directly or indirectly to have casual sexual intercourse without the use of condoms. Furthermore, the early initiation in sexual activity combined with the multiplicity of partners, are considered to be susceptibility factors for the contamination by STI/HIV/AIDS [7].

In the view of the above, the present study had as an objective to identify the sources of information about STI/HIV/AIDS used by adolescent students.

\section{Method}

This is an exploratory, descriptive and transversal field study, with a quantitative approach, carried out in a public high school, located in the urban 
zone of the municipality of Cajazeiras/PB, with 188 adolescents of a population base of 288 students, between the months of February and March 2015.

The participation of the adolescents in the study used the following inclusion criteria: to be in the 14-19 age group, to be regularly enrolled in the institution and attending secondary education, and to accept to participate in the research by the signature of the Informed Consent Form, by the students themselves of by the parents, when the individuals were under 18 years of age.

The data collection was carried out during the school term period, by means of the application of a previously elaborated questionnaire, with socialdemographic questions and referring to the information sources about STI/HIVIAIDS to which the adolescents have access. The collected data was stored in a spreadsheet structures in the Microsoft Excel Program, and were imported and analyzed using the SPSS (Statistical Package for the Social Science) for Windows, version 21.

The research project was approved by the Ethics in Research Committee of the Center for Teacher Development/Federal University of Campina Grande under the CAAE n 139134614.0.0000.5575 and protocol number 941.598 .

\section{Results}

Table 1 presents the characterization of the participants which occurred by the analysis of the data and the elaboration of the population's profile. It was observed that the was a predominance of females (66\%), in the 17- 19 age group (64.9\%), of black/brown-skinned color/race (64.9\%), without a partner $(91.5 \%)$, catholic by religion $(81.9 \%)$, with a Family income of up to a minimum salary $(41.5 \%)$ not engaged in labor activities (75.5\%).

In Table $\mathbf{2}$ are expressed the sources of information about STI/HIVIAIDS, according to the gender of the participants. The school was cited as the main source of information for both genders, being $93.5 \%$ for the female gender and $87.5 \%$ for the
Table 1. Social and demographic profile of the study participants, Cajazeiras - PB, 2015. $(n=188)$.

\begin{tabular}{|l|c|c|}
\multicolumn{1}{|c|}{ Variables } & $\mathbf{n}$ & $\%$ \\
\hline Gender & & \\
\hline Female & 124 & 66.0 \\
\hline Male & 64 & 34.0 \\
\hline Age group & & \\
\hline $14-16$ years & 66 & 35.1 \\
\hline $17-19$ years & 122 & 64.9 \\
\hline Color/race & & \\
\hline White & 66 & 35.1 \\
\hline Black/Brown-skinned & 122 & 64.9 \\
\hline Marital status & & \\
\hline Without a partner & 172 & 91.5 \\
\hline With partner & 16 & 8.5 \\
\hline Religion & & \\
\hline Catholic & 154 & 81.9 \\
\hline Evangelical & 18 & 9.6 \\
\hline Without & 12 & 6.4 \\
\hline Other & 4 & 2.1 \\
\hline Labor activity & & \\
\hline Yes & 46 & 24.5 \\
\hline No & 142 & 75.5 \\
\hline Family income & & \\
\hline$\geq 1$ minimum salary & 78 & 41.5 \\
\hline Between 2 and 3 minimum salaries & 56 & 29.8 \\
\hline Not informed & 54 & 28.7 \\
\hline Total & 188 & 100.0 \\
\hline & Source: Field research, 2015. \\
\hline
\end{tabular}

Table 2. Distribuition of participants according to the gender and the sources of information about STI/HIVIAIDS, Cajazeiras - PB, 2015. ( $n=188)$.

\begin{tabular}{|l|c|c|c|c|}
\hline \multicolumn{1}{|c|}{$\begin{array}{c}\text { Sources of } \\
\text { information }\end{array}$} & \multicolumn{2}{|c|}{ Female } & \multicolumn{2}{c|}{ Male } \\
\hline $\begin{array}{l}\text { Media } \\
\text { Health clinics }\end{array}$ & 6 & 4.8 & 4 & 6.3 \\
\hline $\begin{array}{l}\text { Community health } \\
\text { agent }\end{array}$ & 26 & 21.0 & 14 & 21.9 \\
\hline $\begin{array}{l}\text { School } \\
\text { Parents }\end{array}$ & 116 & 93.5 & 56 & 87.5 \\
\hline Friends & 12 & 9.7 & 12 & 18.8 \\
\hline Work & 28 & 22.6 & 6 & 9.4 \\
\hline Total & - & - & 2 & 3.1 \\
\hline
\end{tabular}

Note: More than one alternative could be chosen.

Source: Field research, 2015. 
male gender, followed by the media, with $38.7 \%$ females and $40.6 \%$ male.

\section{Discussion}

188 adolescents participated in this study, of which the majority were female, which represents a common reality among the Brazilian population, in view of the fact that in 2002 the total of women corresponded to $50.8 \%$ of the population, whilst in 2012, this number increased to $51.3 \%$ [8].

The age group which concentrated the highest number of adolescents was 17-19, a fact that may be related to the feeling of responsibility experienced by the individual in this phase of life, resulting, mainly, from the rights and duties arising from the civil majority, thus making it more attractive the idea of participating in a research and to be able to sign a document without the need of permission from parents or guardians [9].

In relation to the race/color, it was observed a higher prevalence of black or brown-skinned adolescents (64.9\%), corroborating with the data found in the national demographic census carried out in 2010, which reveals that the Brazilian population is composed, in its majority, by self-declared black or brown-skinned people, totaling more than 96 million individuals, which corresponds to $50.74 \%$ of the population [10].

The most cited marital status by the adolescents was without a partner (91.5\%), a fact that may represent an increased vulnerability to IST/HIVIAIDS, as it favors the multiplicity of partners, especially among the men, who are encouraged and influenced by the idea of masculinity and virility being associated to the greater number of sexual partners, which increases the possibilities of contracting sexual infections [11-12]. However, the presence of a partner and of a stable relationship do not provide immunity to STI/HIV/AIDS, as it is quite common the presence of extramarital relations, mostly amongst the young population [13].
Regarding religion, $93.6 \%$ of the adolescents stated to have religious practices, of which $81.9 \%$ declared to be catholic. The Roman Catholic Apostolic religion presents the highest prevalence of followers in all the country, with more than 123 million believers, which corresponds to $64.6 \%$ of the Brazilian population [14]. Therefore, a more complex investigation is necessary regarding the aspects which relate the religiosity to the young people's vulnerability to STI/HIVIAIDS, seen as religion may present a negative influence on the sexual education, repressing young people in relation to the expression of their sexuality and regarding the adoption of safe preventive practices [15-16].

When questioned about the performance of labor activities, $24.5 \%$ of the adolescents said they worked, what may be justified by the low family income of these individuals, being in the majority of cases of up to a minimum salary, which corresponds to $R \$ 724,00$. Such reality directly influences the precocious entry of these adolescents into the work market, as they seek to complement the family income or to provide their own sustenance, which may contribute to leaving school and increase their vulnerability to STIs [17-18].

In relation to the sources of information about STI/HIVIAIDS accessible to the young people researched, it has become clear, that for both genders there was a predominance of the school and the media. The school environment has an important function in the construction of the adolescent's character and personality, being considered as a propitious space for the development and transmission of knowledge, enabling the formation of citizens who will collaborate with the health professionals in the act of educating, being disseminators of valuable knowledge [19-20].

School has the commitment to encourage the concern and responsibility of the adolescent public with self-care, seeking to promote in these individuals the ability to decide about safe sexual practices [2]. This way, the school must approach sexuality 
with a broader perspective, considering the various factors which directly or indirectly interfere in the sexual practices of these individuals, such as social, cultural and economic aspects, the sexual orientation, gender and vulnerability issues, and not only the biological/reproductive sphere [21].

Regarding the media, the television and the internet should be highlighted as sources of information about sexuality for adolescents, due to their easy access and for suppressing the empty spaces left by an education which should have been offered at school and by the Family [22]. On the other hand, the information from these communication means, are generally incorrect or insufficient, being incapable of propitiating the adequate clarification of the questions related to the theme, which promotes a false conception of knowledge about the STI/HIV/ AIDS [6, 9, 23].

It was evident the little participation of the parents and of the health clinics in the context of the transfer of knowledge about STI/HIV/AIDS. In the first case, this may be justified, in principle, by the resistance of the parents and guardians, to discuss and explore the topic of sexuality with the adolescents, which may be attributed to educational and/or cultural issues, to the lack of knowledge, to shame, insecurity and prejudice inherent for each person $[11,24]$. With regard to the health clinics, a greater intervention of the professional working in these services is necessary, so as to promote sexual education for the adolescents, communicating relevant knowledge, clarifying pertinent doubts and encouraging the adoption of efficient preventive practices $[20,25]$.

\section{Conclusion}

It was observed that the social and economic spheres may increase the adolescents' vulnerability to STI/HIV/AIDS, and interventions are necessary on the part of the health professional which seek to reduce these individuals' susceptibility and provide a greater knowledge about the complexities which involve the topic of sexuality among young people.

It was possible to identify that the school had a relevant contribution for the dissemination of knowledge about the STI/HIVIAIDS, being referred to as the main source of information. Thus, we noticed that the school environment plays a complementary and fundamental role in the health promotion of these adolescents, by means of the approach in the classroom, of subjects related to sexuality. However, it is believed that such discussion occurs in a superficial form, not clarifying completely the doubts and questions which may influence the adoption of safe preventive practices.

Faced with this, it is necessary that the health professional observe the school as an important health space, which must become a routine environment for the development of health education actions and strategies, especially for the topics related to the experiences of the sexuality in the adolescent phase.

\section{References}

1. Sawyer SM, Afifi RA, Bearinger LH, Blakemore SJ, Dick B, Ezeh $A C$ et al. Adolescence: a foundation for future health. Lancet [Internet], 2012 Apr; 28(379): 1630-40. DOI: 10.1016/S01406736(12) 60072-5.

2. Camargo EAl, Ferrari RAP. Adolescentes: conhecimentos sobre sexualidade antes e após a participação em oficinas de prevenção. Ciênc Saúde Coletiva [Internet], Rio de Janeiro, 2009 May/June; 14(3): 937-46. DOI: http://dx.doi.org/10.1590/S1413$\underline{81232009000300030}$

3. OMS (Organização Mundial da Saúde). Módulo de Treinamento: Vigilância da Infecção pelo HIV. Programa Mundial de Controle da AIDS. Genebra: OMS; 1993.

4. Ministério da Saúde (BR). Boletim Epidemiológico HIVAIDS. Ano II n 01. Brasília: Ministério da Saúde; 2013. Available from: http://www.aids.gov.br/sites/default/files/ anexos/publicacao/2013/55559/_p boletim_2013 internet pdf p 51315.pdf

5. Ministério da Saúde (BR). Boletim Epidemiológico HIVAIDS. Ano IV n 01. Brasília: Ministério da Saúde; 2015. Available from: http://www.aids.gov.br/sites/default/files/ anexos/publicacao/2015/58534/boletim aids 112015 web pdf 19105.pdf 
6. Coelho RFS, Souto TG, Soares LR, Lacerda LCM, Matão MEL. Conhecimentos e crenças sobre as Doenças Sexualmente Transmissíveis e HIVIAIDS entre adolescentes e jovens de escolas públicas estaduais da Região Oeste de Goiânia. Rev Patologia Tropical [Internet], 2011 Jan/Mar; 40(1): 56-66. Available from: http://www.revistas.ufg.br/index.php/iptsp/article/view/13914

7. Folch C, Casabona J, Muñoz R, González V, Zaragoza K. Incremento en la prevalencia del VIH y en las conductas de riesgo asociadas en hombres que tienen sexo con hombres: 12 años de encuestas de vigilancia conductual en Cataluña. Gac Sanit [Internet], 2010; 24(1): 40-6. DOI: 10.1016/j.gaceta.2009.06.010

8. Departamento de Informática do Sistema Único de Saúde (DATASUS). Indicadores demográficos-população total. On line [Internet]. Available from: http://tabnet.datasus.gov.br/cgi/ tabcgi.exe?idb2012/a01.def

9. Jardim VMJ, Nominato LT, Ghetti PAO, Lauriano MM, Gadêlha TA, Schmith PM et al. O conhecimento e o uso de preservativo por adolescentes: estudo comparativo em uma escola particular e pública. Rev Científica da Faculdade de Medicina de Campos [Internet], 2013 May; 8(1): 8-13. Available from: http://www.fmc.br/revista/V8N1P08-13.pdf

10. Instituto Brasileiro de Geografica e Estatística (IBGE). Censo Demográfico 2010-Características da população e dos domicilios [Internet]. Available from: http://www.ibge.gov.br/ home/estatistica/populacao/censo2010/caracteristicas da populacao/tabelas pdf/tab3.pdf

11. Bertoni N, Bastos FI, Mello MB, Makuch MY, Sousa MH, Osis MJ et al. Uso de álcool e drogas e sua influência sobre as práticas sexuais de adolescentes de Minas Gerais, Brasil. Cad Saúde Pública [Internet], Rio de Janeiro, 2009 June; 25(6): 1350-60. DOI: http://dx.doi.org/10.1590/S0102-311X2009000600017

12. Melo HMA, Leal MCC, Marques APO, Marino JG. O conhecimento sobre Aids de homens idosos e adultos jovens: um estudo sobre a percepção desta doença. Ciênc. Saúde Coletiva [Internet], Rio de Janeiro, 2012 Jan; 17(1): 43-53. DOI: http://dx.doi.org/10.1590/\$1413-81232012000100007

13. Silva CM, Vargens OMC. A percepção de mulheres quanto à vulnerabilidade feminina para contrair DST/HIV. Rev ESC Enferm USP [Internet], São Paulo 2009 June; 43(2): 401-6. DOI: http://dx.doi.org/10.1590/S0080-62342009000200020

14. Instituto Brasileiro de Geografica e Estatística (IBGE). Censo Demográfico 2010-Características gerais da população, religião e pessoas com deficiência [Internet]. Available from: http:// www.ibge.gov.br/home/presidencia/noticias/imprensa/ppts/00 000009352506122012255229285110.pdf

15. Ferreira AGN, Silva KL, Sousa PRM, Gubert FA, Vieira NFC, Pinheiro PNC. Cultura masculina e religiosidade na prevenção das DST/HIV/aids em adolescentes. REME Rev Min Enferm [Internet], 2012; 16(4): 572-8. DOI: http://www.dx.doi.org/ $\underline{S 1415-27622012000400013}$

16. Conferência Nacional dos Bispos do Brasil (CNBB). Catecismo da Igreja Católica: edição revisada de acordo com o texto oficial em latim. São Paulo: Ave-maria; 2009.

17. Cacciamali MC, Tatei F, Batista NF. Impactos do Programa Bolsa Família Federal sobre o trabalho infantil e a frequência escolar. Rev Econ Contemp [Internet], Rio de Janeiro, 2010 May/Ago; 14(2): 269-301. DOI: http://dx.doi.org/10.1590/ S1415-98482010000200003
18. Camargo BV, Giacomozzi Al, Wachelke JFR, Aguiar A. Relações amorosas, comportamento sexual e vulnerabilidade de adolescentes afrodescendentes e brancos em relação ao HIV/ AIDS. Saúde Soc [Internet], São Paulo, 2010 Dec; 19(Supl 2): 3650. DOI: http://dx.doi.org/10.1590/S0104-12902010000600005

19. Gomes JP. As Escolas Promotoras de Saúde: uma via para promover a saúde e a educação para a saúde da comunidade escolar. Educação [Internet]. Porto Alegre, 2009 Jan/Apr; 32(1): 84-91. Available from: http://revistaseletronicas.pucrs.br/ojs/ index.php/faced/article/download/5229/3858

20. Gubert FA, Santos ACL, Aragão KA, Pereira DCR, Vieira NFC, Pinheiro PNC. Tecnologias educativas no contexto escolar: estratégia de educação em saúde em escola pública de Fortaleza-CE. Rev Eletr Enf [Internet], Porto Alegre, 2009; 11(1): 165-72. AVailable from: https://www.fen.ufg.br/fen revista/ v11/n1/pdf/v11n1a21.pdf

21. Ministério da Saúde (BR). BRASIL. Saúde sexual e saúde reprodutiva [Internet]. Série $A$. Normas e Manuais Técnicos Cadernos de Atenção Básica, n. 26. Brasília, DF: Ministério da Saúde, 2006. 299 p. Available from: http://189.28.128.100/dab/ docs/publicacoes/cadernos ab/abcad26.pdf.

22. Santos SMS, Oliveira MLF. Conhecimento sobre AIDS e drogas entre alunos de graduação de uma instituição de ensino superior do estado do Paraná. Rev Latino-Am Enferm [Internet], Ribeirão Preto, 2009 July/Ago; 17(4): 522-8. DOI: http://dx.doi. org/10.1590/S0104-11692009000400014

23. Oliveira DC. Conhecimentos e práticas de adolescentes acerca das DST/HIVIAIDS em duas escolas públicas municipais do Rio de Janeiro. Esc Anna Nery [Internet], Rio de Janeiro, 2009 Oct/Dec; 13(4): 833-41. DOI: http://dx.doi.org/10.1590/S1414$\underline{81452009000400020}$

24. Freitas KR, Dias SMZ. Percepção de adolescentes sobre sua sexualidade. Texto Contexto Enferm [Internet], Florianópolis, 2010; 19(2): 351-7. Available from: http://www.scielo.br/pdf/ tce/v19n2/17.pdf

25. Barbosa SM, Dias FLA, Pinheiro AKB, Pinheiro PNC, Vieira NFC. Jogo educativo como estratégia de educação em saúde para adolescentes na prevenção às DST/AIDS. Rev Eletr Enf [Internet], Goiânia, 2010; 12(2): 337-41. DOI:10.5216/ree.v12i2.6710

\section{Publish in International Archives of Medicine}

International Archives of Medicine is an open access journal publishing articles encompassing all aspects of medical science and clinical practice. IAM is considered a megajournal with independent sections on all areas of medicine. IAM is a really international journal with authors and board members from all around the world. The journal is widely indexed and classified Q1 in category Medicine. 